\title{
DETECTION OF VIRULENCE GENES IN SALMONELLA ENTERITIDIS ISOLATED FROM DIFFERENT SOURCES
}

\author{
Sílvia Dias de Oliveira ${ }^{1,2,3 *}$; Carla Rosane Rodenbusch ${ }^{3}$; Geovana B. Michael ${ }^{3}$; Marisa I.R. Cardoso ${ }^{3}$; \\ Cláudio Wageck Canal ${ }^{3}$; Adriano Brandelli²
}

${ }^{1}$ Departamento de Ciências Microbiológicas, Faculdade de Biociências, Pontifícia Universidade Católica do Rio Grande do Sul, Porto Alegre, RS, Brasil. ' Instituto de Ciências e Tecnologia de Alimentos, Universidade Federal do Rio Grande do Sul, Porto Alegre, RS, Brasil. ${ }^{3}$ Faculdade de Veterinária, Universidade Federal do Rio Grande do Sul, Porto Alegre, RS, Brasil.

This paper corresponds to an "extended abstract" selected for oral presentation in the $22^{\text {nd }}$ Brazilian Congress of Microbiology, held in Florianópolis, SC, Brazil, in November 17-20, 2003

\begin{abstract}
The presence of three virulence genes, invA, $s p v \mathrm{R}$, and $s p v \mathrm{C}$, was determined in Salmonella Enteritidis isolated from poultry, pigs, humans and food. All isolates were positive for the invA gene, with $91.2 \%$ being positive for $s p v \mathrm{R}$ and $90.2 \%$ for $s p v \mathrm{C}$. There was no significant difference in the prevalence of the virulence genes between isolates from different sources. The results indicate that there is a putative high virulence potential for the $S$. Enteritidis isolates characterized.
\end{abstract}

Key words: Salmonella Enteritidis, virulence, spv, PCR.

\section{INTRODUCTION}

Salmonellosis is one of the most common infectious diseases of both humans and animals and since the 1980's there has been a dramatic world-wide increase in the number of reported isolations of $S$. Enteritidis (6).

The virulence of Salmonella is linked to a combination of chromosomal and plasmid factors, the chromosomally located invasion gene invA being thought to trigger the invasion of salmonellae into cultured epithelial cells (1), while an operon ( $s p v \mathrm{RABCD})$, containing five genes, is present on plasmids commonly associated with some serotypes, the $s p v$ genes possibly having the ability to increase the severity of enteritis and allow infection and persistence at extraintestinal sites (3).

The purpose of our study was to asses the potential virulence of $S$. Enteritidis isolates from poultry, pigs, humans and food by detecting the presence of the $i n v \mathrm{~A}, s p v \mathrm{R}$ and $s p v \mathrm{C}$ virulence genes using the Polymerase Chain Reaction (PCR).

\section{MATERIALS AND METHODS}

\section{Bacterial strains}

Our study used $102 \mathrm{~S}$. Enteritidis strains isolated in Southern Brazil, 31 from food involved in foodborne outbreaks, 22 from broiler carcasses, 21 from poultry (viscera and environmental samples), 17 from humans and 11 from pigs (lymph nodes, faeces and fresh pork sausage).

\section{PCR}

DNA was extracted as previously described (4). PCR was performed with three sets of primer pairs: 139-141, specific for the invasion gene invA (4); PG 48-PG49, specific for the $s p v \mathrm{R}$ gene (7); and VIR113-VIR561 specific for the $s p v C$ gene (5), amplifying $284 \mathrm{bp}, 890 \mathrm{bp}$ and 472 bp DNA fragments, respectively (Fig. 1). PCR amplifications were performed in a final volume of $25 \mu \mathrm{L}$ containing DNA template, $1.5 \mathrm{mM} \mathrm{MgCl}_{2}$, $10 \mathrm{mM}$ Tris $\mathrm{HCl}$ (pH 8.0), $50 \mathrm{mM} \mathrm{KCl}, 0.2 \mathrm{mM}$ of each nucleotide, $0.8 \mathrm{pmol} / \mu \mathrm{L}$ of each primer and $1 \mathrm{U}$ of Taq DNA polymerase.

*Corresponding author. Mailing address: Departamento de Ciências Microbiológicas, Faculdade de Biociências, Pontifícia Universidade Católica do Rio Grande do Sul, Av. Ipiranga 6681. 90619-900, Porto Alegre, RS, Brasil. E-mail: silviadias@pucrs.br 


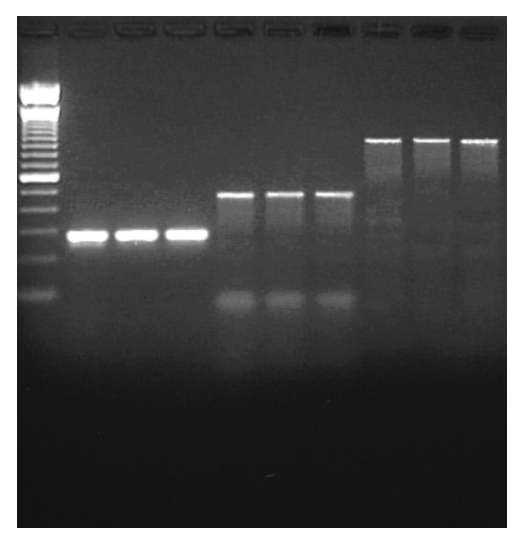

Figure 1. Electrophoreses of PCR: 100 bp molecular weight marker (lane 1); fragment from invA primers (lanes 2 to 4); fragment from $s p v \mathrm{C}$ primers (lanes 5 to7); fragment from $s p v \mathrm{R}$ primers (lanes 8 to10).

The amplification of the invA gene fragment was carried out as previously described (4), the amplification conditions for the $s p v \mathrm{C}$ gene fragment being similar except that the annealing temperature was $58^{\circ} \mathrm{C}$. Amplification of the $s p v \mathrm{R}$ gene fragment was carried out as previously described (7). Amplification products were separated by electrophoreses on $1.2 \%$ agarose gel stained with $5 \mu \mathrm{g} / \mathrm{mL}$ of ethidium bromide with a $100 \mathrm{bp}$ DNA ladder as molecular weight marker.

\section{RESULTS AND DISCUSSION}

All 102 S. Enteritidis isolates contained the invasion gene invA, other studies having reported similar results $(4,8)$, which was expected since the inv $\mathrm{A}$ is an invasion gene conserved among Salmonella serotypes.

The $s p v \mathrm{R}$ virulence gene was detected in $91.2 \%$ of the $S$. Enteritidis strains and the $s p v \mathrm{C}$ gene in $90.2 \%$, there being no significant difference in the prevalence of virulence genes among the isolates from different sources. Only two strains contained $s p v \mathrm{R}$ but not $s p v \mathrm{C}$; and one strain contained $s p v \mathrm{C}$ but not $s p v \mathrm{R}$. The analysis of the $s p v$ operon has shown that $s p v \mathrm{R}$ is an essential virulence gene while the $s p v \mathrm{C}$ gene plays an accessory role but is probably needed for full virulence (2) and, therefore, it may be concluded that the isolates without the $s p v \mathrm{R}$ gene are probably avirulent while absence of the $s p v \mathrm{C}$ gene may indicate partial virulence.

High prevalence of these virulence genes has also been found by other authors $(5,9)$, although in our isolates from humans and poultry the prevalence of virulence genes was even higher than that already reported. It appears that there may be some variation in the prevalence of some virulence genes because a study involving poultry products, wastewater and human sources found that only $15 \%$ of isolates contained the $s p v \mathrm{C}$ gene (8).
A further conclusion of our study is that because they are not present in all isolates, $s p v$ genes are not appropriate targets for the specific detection of the Enteritidis serovar, although they have been used as such in several studies. However, our results regarding the presence of the invA gene do agree with those of other authors who have found that this gene is a good target for detecting salmonellae.

\section{RESUMO}

\section{Detecção de genes de virulência in Salmonella Enteritidis isoladas de diferentes fontes}

A presença de três genes de virulência (invA, $s p v \mathrm{R}$ e $s p v \mathrm{C}$ ) foi determinada em Salmonella Enteritidis isoladas de aves, suínos, humanos e alimentos. Todos os isolados foram positivos para o gene invA, 91,2\% também foram positivos para o $s p v \mathrm{Re}$ $90,2 \%$ para o $s p v$ C. Não existiu diferença significativa na prevalência dos genes de virulência entre isolados de diferentes origens. Os resultados indicaram que, provavelmente, exista um alto potencial de virulência nos isolados de $S$. Enteritidis caracterizados.

Palavras-chave: Salmonella Enteritidis, virulência, spv, PCR.

\section{REFERENCES}

1. Galan, J.E.; Curtiss III, R. Cloning and molecular characterization of genes whose products allow S. typhimurium to penetrate tissue culture cells. Proc. Natl. Acad. Sci. USA, 86:6383-6387,1989.

2. Guiney, D.G.; Fang, F.C.; Krause, M.; Libby, S.; Buchmeier, N.A.; Fierer, J. Biology and clinical significance of virulence plasmids in Salmonella serovars. Clin. Infect. Dis., 21:S146-S151, 1995.

3. Libby, S.J.; Lesnick, M.; Hasegawa, P.; Weidenhammer, E.; Guiney, D.G. The Salmonella virulence plasmid spv genes are required for cytopathology in human monocyte-derived macrophages. Cell. Microbiol., 2:49-58, 2000.

4. Oliveira, S.D.; Santos, L.R.; Schuch, D.M.T.; Silva, A.B.; Salle, C.T.P.; Canal, C.W. Detection and identification of salmonellas from poultry by PCR. Vet. Microbiol., 87:25-35, 2002.

5. Rexach, L.; Dilasser, F.; Fach, P. Polymerase chain reaction for salmonella virulence-associated plasmid genes detection: a new tool in salmonella epidemiology. Epidemiol. Infect., 112:33-43, 1994.

6. Rodrigue, D.C.; Tauxe, R.V.; Rowe, B. International increase in Salmonella Enteritidis: a new pandemic? Epidemiol. Infect., 105:2127, 1990.

7. Rubino, S.; Muresu, E.; Solinas, M.; Santona, M.; Paglietti, B.; Azara, A.; Schiaffino, A.; Santona, A.; Maida, A.; Cappuccinelli, P. IS200 fingerprint of Salmonella enterica serotype Typhimurium human strains isolated in Sardinia. Epidemiol. Infect., 120:215222, 1998.

8. Swamy, S.C.; Barnhart, H.M.; Lee, M.D.; Dreesen, D.W. Virulence determinants invA and $s p v \mathrm{C}$ in salmonellae isolated from poultry products, wastewater, and human sources. Appl. Environ. Microbiol., 62:3768-3771, 1996.

9. Threlfall, E.J.; Hampton, M.D.; Chart, H.; Rowe, B. Use of plasmid profile typing for survillance of Salmonella enteritidis phage type 4 from humans, poultry and eggs. Epidemiol. Infect., 112:25-31, 1994. 